\title{
Strengthening Teacher Competency through ICARE Approach to Improve Literacy Assessment of Science Creative Thinking
}

\author{
Ridwan Jusuf, Wahyu Sopandi, Ana Ratna Wulan and Udin Syaefudin Sa'ud \\ Universitas Pendidikan Indonesia \\ Bandung-West Java, Indonesia
}

\begin{abstract}
Teacher competency requires current and continuous professional development. ICARE (Introduction, Connection, Application, Reflection, and Extension) is a program designed to develop teachers' competency. This study aims to improve elementary school teachers' competency in literacy assessment, specifically for creative thinking skills in science, through ICARE. Twenty-one elementary school teachers in public elementary schools from urban, suburban, and rural settings were involved. The study was conducted in 40 sessions. Data were collected using pre-test and post-test and observation of training sessions. This study used two tools for data analysis: Normalized Gain (N-Gain) and inferential statistic (t-test). The results show that elementary school teachers in urban, suburban, and rural areas had good knowledge of literacy assessment for creative thinking skills in science. The ICARE approach was very effective in helping the teachers improve their knowledge in creating an assessment instrument of creative thinking skills in science. Further research must involve more teachers, from both public and private elementary schools and other educational institutions.
\end{abstract}

Keywords: Literacy Assessment; Creative Thinking; ICARE Approach.

\section{Introduction}

Low teacher competency is one of the causes of low student competency (Permana, 2017; Normawati, 2014). Quality education depends on highly qualified teachers (Budyartati, 2014). Therefore, a teacher must be competent in educating and teaching students (Bulajeva, 2003). Teachers who are in direct contact with students as they provide guidance will produce quality students (Wardana, 2013). To provide quality education, a teacher must possess, among others, pedagogical, personal, social, and professional competencies. The pedagogical competency of teachers has a central role in the classroom teaching and learning process (Hamdu, Sopandi, \& Nahadi, 2018; Michel, 2018). 
In 2016, the Ministry of Education and Culture reported that over 2 million Indonesian teachers assessed on a range of teacher competencies only scored $48.94 \%$ in pedagogical skills, below the national average of $55 \%$. In addition, $60 \%$ of the respondents stated that they could not understand, implement, process, report, and use the assessment results well (MoE, 2016). It can be inferred that the teachers lacked the techniques and knowledge to measure students' creative thinking. Hence, it is necessary to conduct training to improve the competency of elementary school teachers in making and developing creative thinking assessment instruments. Teachers' ability in assessing science creative thinking skills needs to be improved, specifically through a training program that strengthens their creative thinking assessment skills.

\section{Theoretical Framework}

\subsection{Education and training}

Competency is one of the characteristics of a person related to performance (Spencer \& Spencer, 1993). Competency includes knowledge, skills, attitudes, values, motivation, and beliefs that a person requires to be successful in work (Gupta, 1999; Amolloh, Wanjiru, \& Lilian, 2018). Teachers who use strong literacy assessment will be in a good position to integrate assessment into directed, effective, and efficient learning (Volante \& Fazio, 2007; Cherie, Susan, \& Glenn, 2019).

Education and training can develop intellectual competence and personality (Notoatmodjo, 2003; Al Jabri, Silvennoinen \& Griffiths, 2018) as part of the efforts to develop and improve technical, theoretical, and conceptual abilities. Teacher training programs are necessary to encourage and support teachers in their tasks (European, 2010; Vally, Leen, Dina, Sara \& Maryam, 2019). The lack of teacher training is one of the biggest barriers to proper implementation of a school curriculum (Congress, 1995). Pribadi (2014, p. 23) defines effective training as follows:

"Effective training programs are training programs that touch three domains, namely: cognitive, affective, and psychomotor. Effective training will be carried out in five ways: 1). Needs analysis; needs analysis is used to find out the specific knowledge and skills needed, analyze the knowledge and skills and needs of the teacher to be trained, and develop specific knowledge that is measurable and aim to improve its performance; 2). Designing instructions; training is designed to be suitable for the purpose of deciding, compiling, and producing the contents of the training program, including modules; 3). Performing validation; the design of the training program needs to be validated by experts before it is used, so the results of the training are in accordance with the objectives to be achieved in the training; 4). Training implementation; Validated training programs need to be implemented to teachers so that they can be seen as having an impact on improving teacher knowledge and skills; 5). Evaluation and follow-up; training program evaluation needs to be done to determine the effectiveness of the training program." 
There are several learning models to improve the quality of learning and develop the teaching profession, including Science Education In-service Teacher Training (Yovita, Emmanuel \& Viola, 2013), Critical Event Model (Nadler, 1982), Lesson Study (Lewis, 2000; Kanellopoulou \& Darra, 2018), Model Curriculum, Sustainable Development, Competences, Teacher Training models (Sleurs, 2013), and Introduction, Connection, Application, Reflection, and Extension (ICARE) (Carni, Maknun \& Siahaan, 2017). ICARE is an effective e-learning approach that is active, creative, and fun and based on students' needs (Dimitrova, Mimirinis \& Murphy, 2004).

\subsection{ICARE Approach}

The ICARE approach has been used by researchers interested in improving creative thinking skills of students and teachers (Carni, Maknun \& Siahaan, 2017), promoting student activity (Dimitrova, Mimirinis \& Murphy, 2004), increasing problem-solving skills (Yumiati \& Wahyuningrum, 2015), and developing cognitive abilities in students (Asri, Rusdiana \& Feranie, 2017). However, research on the effectiveness of the ICARE approach in improving teacher competency in developing teaching materials and assessing learning outcomes that promote creative thinking in students has not yet been undertaken. Therefore, this research attempts to integrate the ICARE approach with literacy assessment standard in developing creative thinking for science education.

The ICARE stages correspond to the scientific approach recommended by the Indonesian 2013 national curriculum. ICARE stands for Introduction, Connection, Application, Reflection, and Extension. and it is also known as a student-centred learning model (Carni, Maknun \& Siahaan, 2017). The ICARE learning approach model can provide opportunities for teachers to change student learning experiences through different emphases at each stage (Carni, Maknun \& Siahaan, 2017). The ICARE approach provides opportunities for teachers to create specific modules by considering students' abilities (Dwijayani, 2017).

The ICARE approach is very suitable to develop literacy assessment of creative thinking because it provides training with a balance between theory and practice (Wahyudin, 2010). This training requires teachers to practice organizing science creative thinking instruments in accordance with the material learned (Imania \& Bariyah, 2018). The ICARE learning is uncomplicated because the learning stages are applicable and flexible (Rahmah, Usman, \& Safani, 2017). The ICARE model was shown to have a positive effect in helping teachers implement more meaningful and enjoyable learning (Safitri, 2017; Wahyudin, 2010).

\subsection{Creative Thinking}

Human thinking skills can be classified into two categories, namely Lower Order Thinking Skills (LOTS) and Higher Order Thinking Skills (HOTS) (Brookhart, 2010). Teachers must be aware of students' HOTS in order to conduct quality teaching in science (Anderson \& Krathwohl, 2015). The assessment of the ability to think creatively must use creative thinking questions that can encourage students to think deeply about the subject matter (Barnett \& Francis, 2012; Nitko \& Brookhart, 2011). 
Creative thinking is a fundamental human ability because it encourages someone to approach a problem creatively, so that a better and beneficial outcome is obtained for life (Conklin, 2012; Demirhan \& Köklükaya, 2014, Tung, 2015; Proctor, Romina \& Burnett, 2009). Creative thinking is a process of thinking that has several characteristics. The first characteristic is fluency that is the ability to express true ideas as clearly as possible. The second is flexibility that is the ability to have diverse ideas. The third is originality that is the ability to accept unique and unusual ideas. The last characteristic is elaboration that is the ability to explain ideas so that they are more valuable in the actual context of discussion (LaFrance, 2010; Kim, 2017; Changa, Lib, Chena \& Chung, 2014).

Creative thinking is the ability to develop unusual, high-quality, and appropriate ideas (Gralewsk, 2019). It is a process involving elements of originality, fluency, flexibility, and elaboration (Susanto, 2013). Creative thinking skills are related to the production of new ideas, new ways, new solutions, new methods, and new procedures (Paul \& Elder, 2006; Chiu, 2014).

\section{Method}

The current study is a research and development. The training program was carried out over 40 sessions with 21 elementary school teachers participating. They were from different schools located in the urban, suburban, and rural settings and were all certified teachers, active in the Teacher Working Group Cluster, and had been teaching for more than 5 years.

The study adopted the steps of research and development design (Borg \& Gall, 2007; Creswell, 2016), as follows: (a) Planning a program design, (b) Developing a product, (c) Making an initial product; (d) Validating the initial product; (e) Revising the initial product; (f) Conducting limited testing; (g) Performing analysis and revision of the main product; (h) Carrying out extensive trials; and (i) Conducting analysis and revision of operational products (Borg \& Gall, 2007; Creswell, 2016). The development of the program for strengthening teachers' competency through ICARE approach in this study is illustrated by Figure 1.

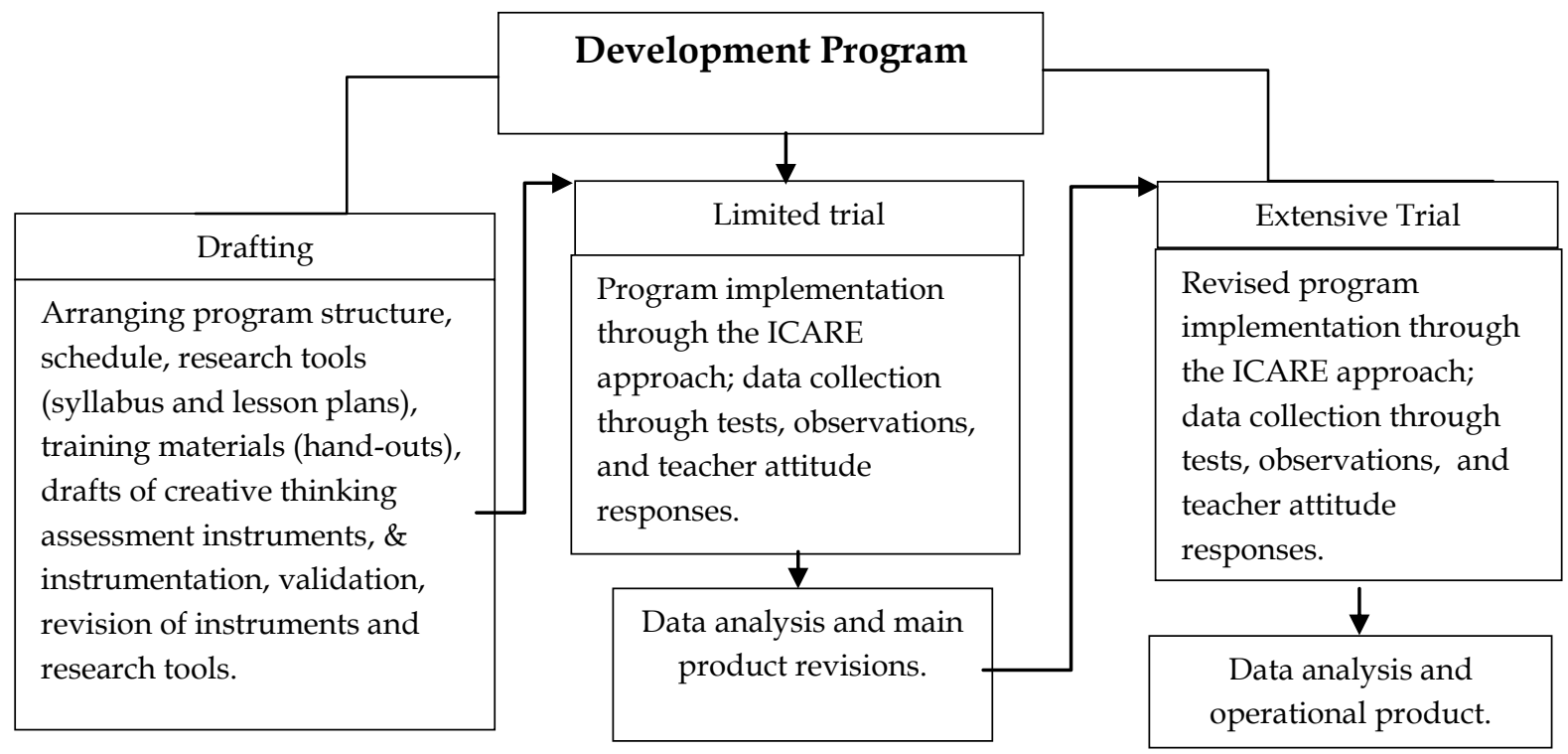

Figure 1. The development of the program for strengthening teacher competency through ICARE approach 
In collecting data, this study used two instruments: test and non-test. The test was designed based on the seven literacy assessment standards proposed by American Federation of Teachers, National Council on Measurement in Education, and National Education Association. The seven literacy assessment standards were developed into 73 multiple choice questions.

The test was conducted twice (pre-test and post-test) to measure the assessment skills of science creative thinking by using the questions on literacy assessment. Meanwhile, the non-test instrument was carried out using an observation sheet designed to gain data related to the implementation of the steps of ICARE approach in this program.

In analysing data, this study used two tools of analysis: Normalized Gain (NGain) and inferential statistic (t-test). Normalized gain (N-Gain) analysis was to determine the increase in participants' knowledge. The participants' knowledge of literacy assessment of science creative thinking was classified into three categories: increased literacy knowledge based on regional characteristics (table 1); increased creative thinking assessment literacy knowledge (table 2), and increased knowledge based on assessment literacy standards (table 3).

This study adopted the pre-experimental one-group pre-test and post-test design. Inferential statistics ( $t$-test) was used to find out the significance of the differences in the improvement of one group in the pre-test and post-test (Creswell 2016; Meltzer, 2002). Therefore, this study used inferential statistics to find out the difference in the participants' improved knowledge of literacy assessment of science creative thinking.

\section{Results and Discussion}

The effectiveness of the ICARE training can be seen from the increased outcomes of the post-test and the significance of the differences between pre- and posttests as measured by N-Gain and $t$-test.

\subsection{Increased Teacher's Knowledge based on Regional Characteristics}

The teacher training program was attended by teacher participants from urban, suburban, and rural areas. The analysis of the pre-test and post-test results is presented in Table 1.

Table 1. Increased Participants' Knowledge Based on Regional Characteristics

\begin{tabular}{|l|l|c|c|c|}
\hline Regional Characteristics & Teacher's Initials & Pre-test & Post-test & N-Gain (\%) \\
\hline \multirow{5}{*}{ Urban } & EST01 & 45 & 67 & 78.6 \\
\cline { 2 - 5 } & EST02 & 42 & 59 & 54.8 \\
\cline { 2 - 5 } & EST12 & 43 & 68 & 83.3 \\
\cline { 2 - 5 } & EST38 & 40 & 62 & 66.7 \\
\cline { 2 - 5 } & EST39 & 43 & 65 & 73.3 \\
\cline { 2 - 5 } & EST 28 & 46 & 67 & 77.8 \\
\cline { 2 - 5 } & EST 35 & 41 & 56 & 46.9 \\
\cline { 2 - 5 } & EST 36 & 54 & 37.9 \\
\hline Average & & & 64.9 \\
\hline
\end{tabular}




\begin{tabular}{|c|c|c|c|c|}
\hline Regional Characteristics & Teacher's Initials & Pre-test & Post-test & N-Gain (\%) \\
\hline \multirow{6}{*}{ Suburban } & EST05 & 35 & 63 & 73.7 \\
\hline & EST09 & 34 & 62 & 71.8 \\
\hline & EST50 & 39 & 64 & 73.5 \\
\hline & EST52 & 33 & 60 & 67.5 \\
\hline & EST 30 & 43 & 66 & 76.7 \\
\hline & EST 21 & 43 & 53 & 33.3 \\
\hline \multicolumn{4}{|l|}{ Average } & 66.1 \\
\hline \multirow{7}{*}{ Rural } & EST17 & 34 & 64 & 76.9 \\
\hline & EST18 & 40 & 56 & 48.5 \\
\hline & EST49 & 37 & 65 & 77.8 \\
\hline & EST56 & 43 & 63 & 66.7 \\
\hline & EST57 & 23 & 63 & 80.0 \\
\hline & EST 20 & 48 & 60 & 48.0 \\
\hline & EST 26 & 63 & 69 & 60.0 \\
\hline \multicolumn{4}{|l|}{ Average } & 65.4 \\
\hline \multicolumn{4}{|l|}{ Overall average } & 65.5 \\
\hline
\end{tabular}

Note: EST (Elementary School Teacher)

The results show that the increase in teachers' knowledge about literacy assessment for science creative thinking was high for all teachers. However, teachers in the suburban area had better knowledge than teachers in the urban and rural areas. The results indicate that location was not a significant factor. In other words, the teachers' ability did not depend on where they lived but their individual characters. Even though some elementary school teachers worked in suburban areas, they had easy access to the city, supported by excellent road facilities. Their schools were located on the same island as Ternate, the capital city of the province. Thus, the teachers in the suburbs could access and keep up with education-related information quickly. What made the difference in the increased knowledge based on regional characteristics significant was the active participation in teacher professional development activities (Thephavongsa, 2018).

4.2. Increased Knowledge of Literacy Assessment for Creative Thinking

The N-Gain analysis results of the assessment of science creative thinking can be seen in table 2. 
Table 2. Increased Literacy Knowledge of Creative Thinking Assessment

\begin{tabular}{|l|c|c|c|}
\hline Teacher's Initials & Pre-test & Post-test & N-Gain (\%) \\
\hline EST01 & 45 & 67 & 78.6 \\
\hline EST02 & 42 & 59 & 54.8 \\
\hline EST12 & 43 & 68 & 83.3 \\
\hline EST38 & 40 & 62 & 66.7 \\
\hline EST39 & 43 & 65 & 73.3 \\
\hline EST 28 & 46 & 67 & 77.8 \\
\hline EST 35 & 41 & 56 & 46.9 \\
\hline EST 36 & 44 & 55 & 37.9 \\
\hline EST05 & 35 & 63 & 73.7 \\
\hline EST09 & 34 & 62 & 71.8 \\
\hline EST50 & 39 & 64 & 73.5 \\
\hline EST52 & 33 & 60 & 67.5 \\
\hline EST 30 & 43 & 66 & 76.7 \\
\hline EST 21 & 43 & 53 & 33.3 \\
\hline EST17 & 34 & 64 & 76.9 \\
\hline EST18 & 40 & 56 & 48.5 \\
\hline EST49 & 37 & 65 & 77.8 \\
\hline EST56 & 43 & 63 & 66.7 \\
\hline EST57 & 23 & 63 & 80.0 \\
\hline EST 20 & 48 & 60 & 48.0 \\
\hline EST 26 & & 69 & 60.0 \\
\hline Average & & & 65.5 \\
\hline
\end{tabular}

Improvement of teacher knowledge about literacy assessment in science creative thinking following the ICARE training was categorized as "high". The teachers' ability to accurately measure students' achievement was considered as an important aspect in teacher professional competency because teacher assessment is frequently the main source of information about student achievement (Südkamp, Kaiser, \& Moller, 2012; Jenkins, 2018).

\subsection{Increased Literacy Assessment Knowledge based on specific Literacy Assessment Standards}

The improvement of teachers' ability to understand literacy assessment of creative thinking using indicators of the Literacy Assessment Standard can be seen in Table 3. 
Table 3. Increased Knowledge Based on Assessment Literacy Standards

\begin{tabular}{|c|l|c|c|c|}
\hline No. & \multicolumn{1}{|c|}{ Literacy Assessment Standards } & $\begin{array}{c}\text { Pre- } \\
\text { test }\end{array}$ & $\begin{array}{c}\text { Post- } \\
\text { test }\end{array}$ & $\begin{array}{c}\text { N-Gain } \\
(\mathbf{\%})\end{array}$ \\
\hline 1. & Choose an assessment method & 50 & 111 & 80.3 \\
\hline 2. & Develop assessment methods & 89 & 126 & 56.9 \\
\hline 3. & $\begin{array}{l}\text { Manage, assign, and interpret } \\
\text { learning outcomes }\end{array}$ & 31 & 70 & 73.6 \\
\hline 4. & $\begin{array}{l}\text { Use the results of the assessment in } \\
\text { decision making }\end{array}$ & 55 & 106 & 71.8 \\
\hline 5. & $\begin{array}{l}\text { Use assessment to determine the } \\
\text { level of learning outcomes }\end{array}$ & 76 & 133 & 73.1 \\
\hline & $\begin{array}{l}\text { Communicate the results of the } \\
\text { assessment }\end{array}$ & 44 & 56 & 46.2 \\
\hline 7. & Know unethical practices & 45 & 59 & 56.0 \\
\hline Average & & 65.4 \\
\hline
\end{tabular}

Teachers' knowledge and competency after participating in the training increased by $65.4 \%$. The results indicate that the training using the ICARE approach had a significant impact on teachers' understanding of literacy assessment of science creative thinking and on their ability to make instruments of science creative thinking assessment. Class activities are indeed effective ways of promoting students' creative thinking. This result is in line with that of previous studies showing that ICARE model had a positive effect and generated more meaningful and enjoyable learning (Safitri, 2017; Wahyudin, 2010).

\subsection{The Significance of the Increased Knowledge about Literacy Assessment for Creative Thinking}

The effectiveness of the ICARE approach in strengthening teacher competency was evaluated based on the significance of the difference in the teachers' knowledge. The differences in the teachers' increased knowledge are presented in Table 4 below.

Table 4. Differences in test result

\begin{tabular}{|c|c|c|c|c|}
\hline No & Pre-test & Post-test & $\mathbf{d}$ & $\mathbf{d}^{\mathbf{2}}$ \\
\hline 1 & 45 & 67 & 22 & 484 \\
\hline 2 & 42 & 59 & 17 & 289 \\
\hline 3 & 43 & 68 & 25 & 625 \\
\hline 4 & 40 & 62 & 22 & 484 \\
\hline 5 & 43 & 65 & 22 & 484 \\
\hline 6 & 46 & 67 & 21 & 441 \\
\hline 7 & 41 & 56 & 15 & 225 \\
\hline 8 & 44 & 55 & 11 & 121 \\
\hline 9 & 35 & 63 & 28 & 784 \\
\hline 10 & 34 & 62 & 28 & 784 \\
\hline 11 & 39 & 64 & 25 & 625 \\
\hline 12 & 33 & 60 & 27 & 729 \\
\hline 13 & 43 & 66 & 23 & 529 \\
\hline
\end{tabular}




\begin{tabular}{|c|c|c|c|c|}
\hline No & Pre-test & Post-test & $\mathbf{d}$ & $\mathbf{d}^{\mathbf{2}}$ \\
\hline 14 & 43 & 53 & 10 & 100 \\
\hline 15 & 34 & 64 & 30 & 900 \\
\hline 16 & 40 & 56 & 16 & 256 \\
\hline 17 & 37 & 65 & 28 & 784 \\
\hline 18 & 43 & 63 & 20 & 400 \\
\hline 19 & 23 & 63 & 40 & 1600 \\
\hline 20 & 48 & 60 & 12 & 144 \\
\hline 21 & 63 & 69 & 6 & 36 \\
\hline
\end{tabular}

Note: difference in post-test and pre-test scores (d)

The paired $t$-test yielded $t_{\text {stat }}=9.807$ and $t_{\text {table }}=1.725$ at the significance level of $5 \%$, df $=\mathrm{N}-1=20$. Since $t_{\text {stat }}>t_{\text {table }}(9.807>1.725)$, it can be concluded that statistically, there were significant differences between the teachers' literacy assessment knowledge of science creative thinking before and after the training of strengthening teacher competency through ICARE approach. This shows that the ICARE training strengthened teachers' competency and provided good assessment knowledge for creative thinking. In other words, the teachers improved their ability to make instruments of creative thinking skill tests that can promote and develop students' creative thinking skills. This result shows that elementary school teachers need thinking skills, such as creative thinking skills or Higher Order Thinking Skills (HOTS) (Massa 2014; Hürsen, Kaplan, Özdalc, 2014; Craft ,Cremin, Hay \& Clack, 2014). The ICARE approach was very effective for improving creative thinking, problem-solving, and motivation, and promoting good creative attitude for elementary school students (Carni, Maknun \& Siahaan, 2017; Faulina \& Fitria, 2017; Al Mahalli, 2017; Eliyawati, 2017; Lucchiari, Sala \& Vanutelli, 2019).

The observations conducted during training activities also show that the training for teacher professional development could improve the performance of professional teachers well. The training could improve the teacher's ability to perform efficiently in a process (Saleem, Mehwish \& Akram, 2011). This is in line with the argument that training is an effective tool to create individuals who are able to use their capacity and potential (Asim, 2013; Khanfar, 2011). In addition, five dominant factors in improving the quality of education are leaders, teachers, students, curriculum, and collaborative networks (Konstantinos, 2018). Learning outcomes need to be assessed, and the result of the assessment can be used as feedback, input, and starting point. Teachers must develop their literacy assessment of science creative thinking skills by participating in various teacher professional development activities conducted by the central and regional governments. The trainings will help them to become professional teachers in carrying out their duties as educators and teachers for elementary school students, strengthening the competencies they have obtained through professional education (Abidin, 2016). 


\section{Conclusions}

Training using the ICARE approach was given to teachers to make it easier for teachers to conduct assessments in learning related to their tasks. The research and development design of this study was conducted by following the steps of the ICARE approach. There was improvement in the participants' knowledge about literacy assessment for creative thinking.

The ICARE approach is effective for training teachers in understanding, designing and creating learning media and creative thinking instruments. Therefore, it is hoped that education policy makers can use the ICARE approach as an alternative solution for developing teachers' assessment literacy. Teachers who have good assessment literacy will be able to develop higher quality thinking instruments. Quality instruments will be able to stimulate students' high-level thinking.

The teachers involved in the study taught in public elementary schools under the Ministry of Education and Culture. It means that teachers at private elementary schools or schools under the Ministry of Religious Affairs were not included. In addition, only one teacher from each school participated in this study. The purposive sampling technique was used to obtain a representative sample of teachers based on regional characteristics. Considering these limitations, the results of the study do not represent all elementary teachers in the region. Further research must involve more teachers, namely teachers of both public and private elementary schools and from other educational institutions.

\section{Acknowledgement}

This research was funded as part of "Dissertation Grants Fund" program from the Ministry of Research, Technology and Higher Education in 2018, with Contract Number: 010/PEN-DD/PL/2018.

\section{References}

Abidin, Y. (2016). Revitalisasi Penilaian Pembelajaran dalam Konteks Pendidikan Multiliterasi Abad Ke-21. Bandung: Refika Aditama.

Al-Mahali, A. J. (2017). Pengembangan model pembelajaran ICARE (Introduction, Connection, Application, Reflection, Extension) pada ekspansi kelas yang sesuai dengan kultur dan karakter siswa di SDN Gedongan 2 dan SDN Meri 2 Kota Mojokerto. Progressa: Journal of Islamic Religious Instruction, 1(1), 59-70. doi.org/10.32616/pgr.v1.1.7.59-70

Amolloh, O. P., Wanjiru, K. G., \& Lilian, G. K. (2018). Work-based Learning, Procedural Knowledge and Teacher Trainee Preparedness towards Teaching Practice at the University of Nairobi, Kenya. International Journal of Learning, Teaching and Educational Research, 17(3), 96-110. doi.org/10.26803/ijlter.17.3

Al Jabri, M. J. H., Silvennoinen, H., \& Griffiths, D. (2018). Teachers' Professional Development in Oman: Challenges, Efforts and Solutions. International Journal of Learning, Teaching and Educational Research, 17(5), 82-103. doi.org/10.26803/ijlter.17.5.6 
Anderson, L. W., \& Krathwohl, D. R. (2015). Kerangka Landasan untuk Pembelajaran Pengajaran dan Asesmen, Yogyakarta: Pustaka Pelajar .

Asim, M. (2013). Impact of Motivation on Employee Performance with effect of training: Specific to Education Sector of Pakistan. International Journal of Scientific and Research Publications, 3(9), 1-9.

Asri, Y. N., Rusdiana, D., \& Feranie, S. (2017, January). ICARE (Introduction, Connection, Application, Reflection, Extension) Model Integrated with Science Magic to Improvement of Students' Cognitive Competence In Heat and Temperature Subject. In International Conference on Mathematics and Science Education. Atlantis Press. doi.org/10.2991/icmsed-16.2017.30

Barnett, J. E., \& Francis, A. L. (2012). Using higher order thinking questions to foster critical thinking: A classroom study. Educational Psychology, 32(2), 201-211. doi.org/10.1080/01443410.2011.638619

Brookhart, S. M. (2010). How to Assess High-er Order Thinking Skills in Your Class-room. Alexandria: ASCD.

Borg, W. R. \& Gall, M. D. (2007). Educational Research, an Introduction. New YorkLondon: Longman.

Budyartati, S. (2014). Problematika Pembelajaran di Sekolah Dasar. Yogyakarta: Deepublish.

Bulajeva, T. (2003). Teacher professional development in the context of school reform. Journal of Teacher Education and Training, 2(2003), 39-45.

Carni., Maknun, J., \& Siahaan, P. (2017, February). An implementation of ICARE approach (Introduction, Connection, Application, Reflection, Extension) to improve the creative thinking skills. In Journal of Physics: Conference Series (Vol. 812, No. 1, p. 012022). IOP Publishing. doi.org/10.1088/1742$6596 / 812 / 1 / 012022$

Changa., Lib., Chena \& Chung. (2014). Investigating the Synergy of Critical Thinking and Creative Thinking in the Course of Integrated Activity in Taiwan. Educational Psychology, 35(3), 341-360. doi.org/10.1080/01443410.2014.920079

Cherie, Mc Collough., Susan, W. M \& Glenn Blalock. (2019). Reforming Science Teacher Education with Cultural Reflection and Practice. International Journal of Learning, Teaching and Educational Research, 18 (1) 31-49. doi.org/10.26803/ijlter.18.1.3

Chiu, F. C. (2015). Improving your creative potential without awareness: Overinclusive thinking training. Thinking Skills and Creativity, 15, 1-12. doi.org/10.1016/j.tsc.2014.11.001

Craft, A., Cremin, T., Hay, P., \& Clack, J. (2014). Creative primary schools: developing and maintaining pedagogy for creativity. Ethnography and Education, 9(1), 16-34. doi.org/10.1080/17457823.2013.828474

Conklin, W. (2012). Higher-Order Thingking Skill to Develop 21st Century Learners. Huntington Beach, California: Shell Education.

Congress, U. S. (1995). Office of technology assessment. Adolescent health, ${ }^{\text {st }}$. doi.org/10.1017/s026646230000533x

Creswell, J. (2016). Riset Pendidikan: Perencanaan, Pelaksanaan, dan Evaluasi Riset Kualitatif dan Kuantitatif. Edisi Kelima. Pustaka Pelajar: Yogyakarta.

Demirhan, E., \& Köklükaya, A. N. (2014). The critical thinking dispositions of prospective science teachers. Procedia-Social and Behavioral Sciences, 116, 15511555. doi.org/10.1016/j.sbspro.2014.01.433 
Dimitrova, M., Mimirinis, M \& Murphy, A. (2004). Evaluating the Flexibility of a Pedagogical Framework for e-Learning. Reprinted from the proceedings of the 3rd ACS/IEEE International Conference on Computer Systems and Applications (AICCSA-05), 03-06 Jan 2005, Cairo, Egypt, pp. 847-852. doi.org/10.1109/icalt.2004.1357422

Dwijayani, N. M. (2017). Pengembangan Media Pembelajaran ICARE. Kreano Jurnal Matematika Kreatif - Inovatif, 8(2), 126-132. doi.org/10.15294/kreano.v8i2.10014

Eliyawati, R. (2017). Peningkatan Mengungkapkan Monolog Deskriptif Lisan Menggunakan Sistem ICARE (Introduction, Connection, Application, Reflection, Extension) Pada Siswa Kelas VII SMPN 1 Karangploso. Konstruktivisme, 9(1), 2017 p-ISSN: 19799438; e-ISSN: 2442-2355 Blitar.

European, U. (2010). Teachers' Professional Development. Europe in International Comparison.

Faulina, F \& Fitria, L. (2017). Pengaruh Model Pembelajaran Contextual Teaching And Learning (CTL) Dengan Pendekatan ICARE (Introduction Connect Apply Eflect and Extend) Terhadap Hasil Belajar Teknologi Informasi Dan Komunikasi. 3 (1), 1-8. Jurnal Bimbingan dan Konseling. P-ISSN: 2527-4244, EISSN : 2541-206X.

Gralewsk, J. (2019). Teachers' Beliefs About Creative Students' Characteristics: A Qualitative Study. Thinking Skills and Creativity. 31 (2019) 138-155. doi.org/10.1016/j.tsc.2018.11.008

Gupta, K. (1999). A Practical Guide For Need Assessment. San Francisco: John Wiley \& Sons. Inc.

Hamdu, G., \& Sopandi, W., \& Nahadi. (2018). Debriefing Program for Prospective Elementary School Teachers in Developing Learning Aids. International Journal of Learning, Teaching and Educational Research, 17(6). doi.org/10.26803/ijlter.17.6.7

Hürsen, C., Kaplan, A \& Özdal, H. (2014). Assessment of Creative Thinking Studies In Terms of Content Analysis. Procedia - Social and Behavioral Sciences 143. doi.org/10.1016/j.sbspro.2014.07.574

Jenkins, K. D. (2018). Understanding Teacher Beliefs and Instructional Decision Making Concerning Disciplinary Literacy: The Case of Secondary Teachers in an Urban School. International Journal of Learning, Teaching and Educational Research 17 (1), 175-196, January 2018. doi.org/10.26803/ijlter.17.1.11

Kanellopoulou, E. M. \& Darra, M. (2018). The Implementation of the Lesson Study Approach to Secondary Education in Greece: The Case of the Literature Lesson. International Journal of Learning, Teaching and Educational Research. 17 (7), 94-105. doi.org/10.26803/ijlter.17.7.6

Khanfar, S. M. (2011). Impact of Training on Improving Hotelling Service Quality. Journal of Business Studies Quarterly. 2(3), 84-93.

Kemendikbud. (2016). Panduan Penilaian untuk Sekolah Dasar (Edisi Revisi). Jakarta: Direktorat Pembinaan Sekolah Dasar.

Kemendikbud. (2016). 7 Provinsi Raih Nilai Terbaik Uji Kompetensi Guru 2015. http:// www.kemdikbud.go.id/2016/01/7-Provinsi-Raih-Nilai-Terbaik-UjiKompetensi-Guru-2015. 
Kim, K. H. (2017). He Torrance Tests of Creative Thinking - Figural or Verbal: Which One Should We Use? Creativity. Theories - Research - Applications, 4(2) 2017. doi.org/10.1515/ctra-2017-0015

Konstantinos, K. (2018). Identifying Potential to Promote the NOS in Elementary Science Teaching Packages. International Journal of Learning, Teaching and Educational Research, 17 (6) 1-18. doi.org/10.26803/ijlter.17.6.1

LaFrance, E. B. (2010). An Insider's Perspective: Teachers Observations of Creative Thinking in Exceptional Children. Roeper Review, 16 (4), 256-257. doi.org/10.1080/02783199409553592

Lewis, C. (2000). Lesson Study: The Core of Japanese Professional Development.

Lucchiari, C., Sala, P. M., \& Vanutelli, M. E. (2019). The effects of a cognitive pathway to promote class creative thinking. An experimental study on Italian primary school students. Thinking Skills and Creativity, 31, 156-166. doi.org/10.1016/j.tsc.2018.12.002

Massa, S. (2014). The development of critical thinking in primary school: the role of teachers' beliefs. Procedia-Social and Behavioral Sciences, 141, 387-392. doi.org/10.1016/j.sbspro.2014.05.068

Meltzer, D. E. (2002). The relationship between mathematics preparation and conceptual learning gains in physics: A possible "hidden variable" in diagnostic pretest scores. American journal of physics, 70(12), 1259-1268. doi.org/10.1119/1.1514215

Michel, A. Y. K. (2018). A pedagogic and didactic use of representations and learning styles for learner engagement: A conceptual framework for teacher mediation. International Journal of Learning, Teaching and Educational Research, 17(3). doi.org/10.26803/ijlter.17.3.7

Nadler, L. (1982). Designing Training Program: The Critical Event Model. MA: AddisonWesley, Reading.

Nitko, A. J \& Brookhart, S. M. (2011). Educational Assessment of Students. (6th ed). Boston: Pearson Education, Inc.

Normawati, S. (2014), Permasalahan Mendasar Pendidikan Di Indonesia. Jurnal Managemen Pendidikan Islam Al-Idarah, 1 (1) 1927, Juli - Desember 2014, Sekolah Tinggi Ilmu Tarbiyah Ar-Risalah, Inhil-Riau.

Noge, M. D. (2017). Efektivitas model pembelajaran ICARE (Introduction, Connection, Application, Reflection, Extension) berbasis media autentik "berbabe" terhadap hasil belajar bahasa inggris siswa sekolah dasar. Tunas Bangsa Journal, $4(2)$.

Notoadmojo, S. (2003). Pengembangan Sumber Daya Manusia. Sekolah Dasar Mahasatya, Jakarta.

Paul, R., \& Elder, L. (2006). Critical thinking: The nature of critical and creative thought. Journal of Developmental Education, 30(2), 34.

Permana, N. S. (2017). Peningkatan Mutu Tenaga Pendidik dengan Kompetensi dan Sertifikasi Guru. Studia Didaktika:Jurnal Ilmiah Bidang Pendidikan, 11 (1), 2017; ISSN 1978-8169. Serang, Banteng.

Pribadi, A. B. (2014). Desain dan Pengembangan Program Pelatihan Berbasis Kompetensi; Implemenasi Model ADDIE. Jakarta: Kencana.

Proctor, R. M., \& Burnett, P. C. (2009). Measuring cognitive and dispositional characteristics of creativity in elementary students. Creativity Research Journal, 16(4), 421-429. doi.org/10.1207/s15326934crj1604_5 
Rahmah, S., Usman, I., \& Safani, J. (2017). Penerapan model ICARE (Introduction Connect Apply Eflect and Extend) terhadap Kemampuan Kognitif dan Keterampilan Berpikir Kritis pada Materi Fluida Dinamis Siswa Kelas XI SMA Negeri 5 Kendari. Kendari. Retrieved from http://sitedi.uho.ac.id/uploads_sitedi/G2J1 15017.pdf

Safitri, T. A. (2017). Penerapan Model Pembelajaran Problem Based Instruction (PBI) berbasis ICARE untuk Meningkatkan Kemampuan Pemecahan Masalah Siswa pada Materi Pencemarn Lingkungan. UIN Sunan Gunung Djati Bandung.

Saleem, Q., Mehwish, S \& Akram, N. (2011). Degree of Influence of Training and Development on Employee Behaviour. International Journal of Computing and Business Research, Vol. 2.

Sleurs, W. (2013). Competencies for ESD (Education for Sustainable Development) teachers. A Framework to Integrate Esd In the Curriculum of Teacher Training Institutes.

Südkamp, A., Kaiser, J \& Möller, Jens. (2012). Accuracy of Teachers' Judgments of Students' Academic Achievement: A Meta-Analysis. Journal of Educational Psychology, 104, 743-762. doi.org/10.1037/a0027627

Susanto. (2013). Teori Belajar dan Pembelajaran di Sekolah Dasar. Jakarta: Fajar Interpratama Mandiri.

Spencer, L. M \& Spencer, S. M. (1993). Competence at Work: Models for Superior Performance, John Wiley \& Sons. New York.

Thephavongsa, S. (2018). Enhancing the Teaching Skills of the Multi-Grade Teachers through Lesson Study. International Journal of Learning, Teaching and Educational Research, 17 (4) 71-87. doi.org/10.26803/ijlter.17.4.5

Tung, K. Y. (2015). Pembelajaran dan Perkembangan Belajar. Jakarta: Indeks.

Volante, L \& Fazio, X. (2007). Exploring Teacher Candidates' Assessment Literacy: Implications for Teacher Education Reform and Professional Development. Canadian Journal of Education, 30(3), 749-770. doi.org/10.2307/20466661

Wardana, D. S. (2013). Motivasi Berprestasi dengan Kinerja Guru yang Sudah Disertifikasi. Jurnal Ilmiah Psikologi Terapan, 1(1), 98-109.

Wahyudin, D. (2010). Model Pembelajaran ICARE (Introduction, Connection, Application, Reflection, Extension) pada Kurikulum Mata Pelajaran TIK di SMP. Jurnal Penelitian Pendidikan, 11(1), 23-33.

Yovita, N. G., Emmanuel, M \& Viola, M. (2013). Empowering Teachers to become Change Agents through the Science Education In-Service Teacher Training Project in Zimbabwe Laurentian University, Emmanuel Mushayikwa University of the Witwatersrand, NorQuest College, Viola.Manokore@NorQuest.ca.

Yumiati \& Wahyuningrum, E. (2015). Pembelajaran ICARE Dalam Tutorial Online Untuk Meningkatkan Kemampuan Pemecahan Masalah Matematis Mahasiswa UT. Jurnal Ilmiah STKIP Siliwangi Bandung, 4 (2) 2015. doi.org/10.22460/infinity.v4i2.81

Vally, Z., Leen, S., Dina, A., Sara, El S., \& Maryam. A. (2019). Examining the Effects of Creativity Training on Creative Production, Creative Self-Efficacy, and NeuroExecutive Functioning Safeya Alsheraifi, Alia Alkaabi. Thinking Skills and Creativity, 31 (2019) 70-78. doi.org/10.1016/j.tsc.2018.11.003 